

\title{
Spatial Analysis Of Buffalo Development In Brebes Regency
}

\author{
Nanang Nur Rozaq ${ }^{1}$ and Mochamad Sugiarto ${ }^{2 *}$ \\ ${ }^{1}$ Animal Husbandry Office of Brebes Regency, \\ ${ }^{2}$ Faculty of Animal Science, Jenderal Soedirman University \\ *Corresponding author : zoegic@yahoo.com
}

Submited : July 2019, Accepted: January 2020, Published : March 2020

\section{HIGHLIGHT}

- The spatial dimension of Buffalo Development in Brebes to analysis buffalo libvestock

- The centralization of buffalo develoment in Brebes Regency is located in Salem, Bumiayu, Sirampog, Tonjong, Larangan and Songgom sub-distric

\section{Keyword}

regional shifting pattern, centralization, farmland

\begin{abstract}
The study on spatial dimension of buffalo development in Brebes is intended to (1) analyze the regional shifting patterns of buffalo development within a period of 5 years (2012-2016) and (2) to identify the relationship between the number of farmland areas and the population of buffalo in Brebes Regency. This research employs a secondary data analysis method by utilizing the available data analyzed using a spatial analysis. Location Quotient (LQ) analysis is conducted to analyze the regional shifting patterns of buffalo followed with a product moment correlation analysis to identify the relationship between the number of farmland areas and the population of buffalo livestock. The results show that the buffalo population is related to the number of rice plant areas $(\mathrm{P}<0.05)$ as well as that of the peanut plant areas $(\mathrm{P}<0.01)$. For the last 5 years $(2012-2016)$, there is no regional shifting pattern in the center for buffalo development in Brebes Regency. The centralization of buffalo develoment in Brebes Regency is located in Salem, Bumiayu, Sirampog, Tonjong, Larangan and Songgom sub-district
\end{abstract}

\section{Introduction}

Each development may result in various changes, including regional opportunities in supporting the development. The development of animal husbandry in Brebes Regency is intended to improve the livestock production, productivity and local resource-based livestock businesses. The availability of land areas and various supporting potentials enable the village to become a strategic areas for the development of buffalo livestock businesses, although industrialization challenges, climate changes and people's migration may become obstacles. Buffalo livestock businesses in
Brebes Regency are mostly cultivated by the breeders as a part of family farming systems with a simple maintenance system. Suhartina and Susanti (2017) stated that buffalo farming are made by the farmers using an extensive system which mostly depends on the natural resources, not yet using the technological interventions. Consequently, the impacts are on poor development of buffalo population. The constructions of housings and industrial estates also lead to the decreasing availability of buffalo farming.

The farmers in Brebes Regency raise buffalo intended only for producing meat and offspring purposes although more benefits may be obtained from the buffalo farming. 
Irshad et al. (2011) state that buffalo is a livestock with various purposes, including as the producer of milk, meat, fertilizer, energy and skin. Buffalo is also utilized for the agricultural production systems, especially for land cultivation. The other benefits of raising buffaloes are due to its higher adaptability in various environmental conditions. Based on its natural characteristics, buffalo may be developed in various parts of Indonesia. In facts, not all areas in Indonesia have buffalo livestock. It is assumed that people's socioculture and customs inhibit the development of certain livestock as well as the availability of animal feed.

The population of buffalo in Brebes increases only by 0.36 percent per year within the last 5 years of 2012-2016 (Central Bureau of Statistics of Brebes Regency, 2017). The population of buffalo is already spread almost in the entire areas of Brebes Regency with 7,650 buffaloes in 2016. The small number of buffalo increase requires a serious attention from the government of Brebes Regency. The development of livestock production, productivity, and agribusiness by optimizing the local resources should be achieved through feed availability and environmental suitability, as well as synergy and harmony with people's social conditions. Regional development results in various changes regarding to the regional supporting power, communities' social economy and climate. Those changes are expected to encourage the dynamic changes in livestock populations in the rural areas. The development of buffalo farming may change their locations depending on the availability of natural and social resources as well as and the other economic possibilities. The possible occurring changes may impact on the development of livestock policy in Brebes Regency. Thus, it is necessary to conduct a study on the regional shifting patterns of buffalo in Brebes Regency.

The objectives of this research are: (1) to analyze the regional shifting patterns of buffalo development in Brebes Regency within a period of 5 years (2012-2016) and
(2) to identify the relationship between the number of farmland areas and the population of buffaloes in Brebes Regency

\section{Research methods}

This research employs a descriptivequantitative method with a Secondary Data Analysis (ADS) approach. Secondary Data Analysis is also considered as a research method. Johnston (2014) stated that Secondary Data Analysis is a further analysis on the available collected data simultaneously presented in major findings of the previous researches. Secondary data are obtained from the Central Bureau of Statistics of Brebes Regency.

To figure out the regional patterns of the buffalo livestock development in Brebes Regency, a Location Quotient Analysis (LQ) approach is employed to examine whether the buffalo farming is considered one base sector or not in one sub-district (Budiharsono, 2001), with the following formula:

Where:

$$
\text { LQ ij }=(X i j / X i) / X . j / X . .
$$

$\mathrm{Xij}=$ population of buffaloes in sub-district $\mathrm{A}$ $\mathrm{Xi}=$ population of livestock in sub-district $\mathrm{A}$ $X . i=$ buffalo population in Brebes Regency $\mathrm{X} . .=$ livestock population in Brebes Regency

If LQ>1 then the commodity of buffalo is considered as a base sector and if $\mathrm{LQ}<1$ then the buffalo is not one base sector in that sub-district.

To identify the relation between the variables of agricultural land area and buffalo population, a product moment correlation analysis is conducted. The correlation is employed to examine the relationship of 2 variables with interval/ ratio data.

$$
r_{x y}=\frac{\sum x y}{\sqrt{\left(\sum x^{2}\right)\left(\sum y^{2}\right)}}
$$

If $r_{x y}>\mathrm{r}$ table of 0.05 , it may be considered that the independent variable has a significant relationship with the dependent variable. Meanwhile, if $r_{x y}<\mathrm{r}$ table of 0.05 , it may be considered that the independent 
variable does not have a significant relationship with the dependent variable.

The regional shifting pattern of the buffalo livestock is analyzed by comparing LQ in 2012 and that in 2016. If LQ in 2012 and that in $2015>1$, it means that there is no regional shifting pattern of buffalo development center. However, if LQ in 2012 and that in 2015 show differences above or below 1, it means that there is a regional shifting pattern of buffalo livestock development center.

\section{Result and Discussion}

\subsection{Agricultural Land Area}

The development of buffalo in a region may not be separated from the availability of animal feed. The total area of
The agricultural crops produce waste products used for the buffalo feed. The buffalo feed fulfillment in Brebes Regency is obtained from the grass land areas on the paddy fields and the agricultural waste

Table 1 shows that the agricultural land areas in Brebes Regency are dominated by rice crops ( 83.76 percent). The land availability for rice crops may influence the supply of grass and rice straw used for the buffalo feed. Bantarkawung, Ketanggungan, Banjarharjo, Bumiayu, Paguyangan, Tonjong, Larangan and Songgom sub-district relatively have more extensive land areas than the other sub-districts do. More extensive availability of agricultural land areas may result in a relatively more livestock feed supply obtained from the

Table 1. Agricultural Crops Land Area

\begin{tabular}{|c|c|c|c|c|c|c|c|c|c|c|c|}
\hline \multirow{2}{*}{ No } & \multirow{2}{*}{ Sub-district } & \multicolumn{2}{|c|}{ Rice } & \multicolumn{2}{|c|}{ Maize } & \multicolumn{2}{|c|}{ Peanut } & \multicolumn{2}{|c|}{ Cassava } & \multicolumn{2}{|c|}{ Sweet Potato } \\
\hline & & 2012 & 2016 & 2012 & 2016 & 2012 & 2016 & 2012 & 2016 & 2012 & 2016 \\
\hline 1 & Salem & 7226.0 & 6443.9 & 47.0 & 28.4 & 31 & 34 & 654 & 428 & 199 & 58.9 \\
\hline 2 & Bantarkawung & 6083.0 & 11659.3 & 995.0 & 2930.1 & 20 & 214 & 175 & 227 & 0 & 0 \\
\hline 3 & Bumiayu & 8103.0 & 7603.5 & 167.0 & 174.8 & 0 & 0 & 240 & 130 & 0 & 0 \\
\hline 4 & Paguyangan & 6026.0 & 6741.6 & 1204.0 & 1058.5 & 63 & 36 & 557 & 308 & 0 & 0 \\
\hline 5 & Sirampog & 6314.0 & 4437.7 & 1471.0 & 1299 & 0 & 0 & 0 & 0 & 0 & 0 \\
\hline 6 & Tonjong & 5834.0 & 6167.0 & 1254.0 & 1479 & 451 & 249 & 179 & 146 & 13 & 19.9 \\
\hline 7 & Larangan & 7990.0 & 6383.6 & 2955.0 & 3192.6 & 0 & 0 & 6 & 0 & 0 & 0 \\
\hline 8 & Ketanggungan & 7090.0 & 7678.1 & 5322.0 & 5051 & 0 & 0 & 0 & 0 & 0 & 0 \\
\hline 9 & Banjarharjo & 9056.0 & 9861.1 & 1732.0 & 1728.3 & 11 & 9 & 0 & 0 & 0 & 0 \\
\hline 10 & Losari & 5087.0 & 6336.9 & 5.0 & 0 & 0 & 0 & 0 & 0 & 0 & 0 \\
\hline 11 & Tanjung & 2634.0 & 2920.9 & 0.0 & 107.9 & 0 & 0 & 0 & 0 & 0 & 0 \\
\hline 12 & Kersana & 1689.0 & 2191.6 & 57.0 & 41 & 0 & 0 & 0 & 0 & 0 & 0 \\
\hline 13 & Bulakamba & 7756.0 & 7044.2 & 0.0 & 0 & 0 & 0 & 0 & 0 & 0 & 0 \\
\hline 14 & Wanasari & 4033.0 & 3635.7 & 4.0 & 0 & 0 & 0 & 0 & 0 & 0 & 0 \\
\hline 15 & Songgom & 8200.0 & 8120.8 & 1686.0 & 611.5 & 0 & 0 & 0 & 0 & 0 & 0 \\
\hline 16 & Jatibarang & 4178.0 & 4870.9 & 549.0 & 678.6 & 0 & 0 & 0 & 0 & 0 & 0 \\
\hline \multirow[t]{2}{*}{17} & Brebes & 2960.0 & 3130.6 & 287.0 & 158.5 & 10 & 0 & 0 & 0 & 0 & 0 \\
\hline & Total Number & 100.259 & 105.227 & 17.735 & 18.539 & 586 & 542 & 1811 & 1239 & 212 & 78.8 \\
\hline
\end{tabular}

agricultural waste. The availability of agricultural by products/waste may have more significant benefits as the competition to obtain animal feed becomes more competitive.

Ilham stated that due to the competition

the harvested agricultural crops may influence the availability of animal feed. Winugroho et al., (1998) state that the production of animal feed material is highly determined by the total area of theharvested agricultural crops, soil condition, and rainfall. The availability of crop waste is based on seasons and fluctuates following the planting patterns and harvest times.

Table 2. Product Moment Correlation Analysis of Agriculture Crop Areas on Buffalo Population

\begin{tabular}{llcc}
\hline No & Independent Variable & $\begin{array}{c}\text { Correlation } \\
\text { Coefficient }(\mathrm{r})\end{array}$ & Significance \\
\hline 1 & Rice crop land area & $0.485^{*}$ & 0.049 \\
2 & Maize crop land area & 0.471 & 0.056 \\
3 & Peanut crop land area & $0.754^{* *}$ & 0.000 \\
4 & Cassava plant land area & 0.475 & 0.054 \\
5 & Sweet potato plant land area & 0.417 & 0.096 \\
\hline
\end{tabular}

$*$ Significant $(\mathrm{p}<0.05)$

** Highly significant $(\mathrm{p}<0.01)$

utilization of byproducts of agricultural industries that have not been widely used. 
Over the past 5 years, the areas of agricultural crops still show stability, especially in rice and maize crops. This condition indicates that the agricultural land areas in Brebes Regency are relatively wellcontrolled and not influenced with the industrial business interests. However, those rice fields tend to decrease in the future due to the influence of housing development and employment transfer from the agricultural to industrial sectors.

The availability of agricultural land areas which influence the provision of agricultural wastes is related to the livestock population in one region. The population of buffalo livestock in each sub-district in Brebes Regency has a strong relationship with rice and peanut plant $(\mathrm{P}<0.01)$. The maize, cassava and sweet potatoe agricultural land areas do not have a significant relationship with the buffalo population. The buffalo is generally adaptable to nature with low feed quality conditions and it may becomes a reason that the extent of agricultural land areas has only small influence on the buffalo population although and the rice straw (hay) may encourage the development of buffalo population. Sumoprastowo (2003) states that buffalo has a very simple life, is easy to maintain, and highly adaptable

In 2016, the population of buffalo has reached 7,650 heads and experienced a

\subsection{The Regional Shifting Patterns of Buffalo Livestock}

The buffalo population increase may be influenced by the technical, socio-cultural, and economic factors. Mukson et al. (2005) stated that the availability of dry land encourages the ruminant population increase and development of livestock in one region. Suhubdy et al. (2005) further explained that the buffalo population decrease in Indonesia is due to the government's focus on cows that the buffalo reproduction rate is poor. Meanwhile, techniques and methods of livestock practices in Indonesia have not adequately supported the buffalo development.

Based on the Location Quotient (LQ) analysis in 2016, it shows that the buffalo farming centralize in Salem, Bumiayu, Sirampog, Tonjong, Larangan and Songgom sub-district. Based on topography, the buffalo farming activities are centralized in the hilly/southern areas of Salem, Bumiayu, Sirampog, Tonjong, Larangan and Songgom

Table 3. The development of ruminant livestock population in Brebes Regency in 2012 - 2016

\begin{tabular}{|c|c|c|c|c|}
\hline \multirow{2}{*}{ No } & \multirow{2}{*}{ Livestock } & \multicolumn{2}{|c|}{ Number (Heads) } & \multirow{2}{*}{$\begin{array}{l}\text { Growth } \\
(\%) / \text { Year }\end{array}$} \\
\hline & & 2012 & 2016 & \\
\hline & BeefCattle & 28.031 & 27.542 & $-0,44$ \\
\hline 2 & Dairy Cow & 50 & 31 & $-15,32$ \\
\hline & Buffalo & 7.540 & 7.650 & 0,36 \\
\hline 4 & Sheep & 173.009 & 168.508 & $-0,67$ \\
\hline 5 & Goat & 116.597 & 108.336 & $-1,91$ \\
\hline
\end{tabular}

sub-district. Salaam, Bumiayu, Sirampog and Tonjong sub-district are located in SubRegional

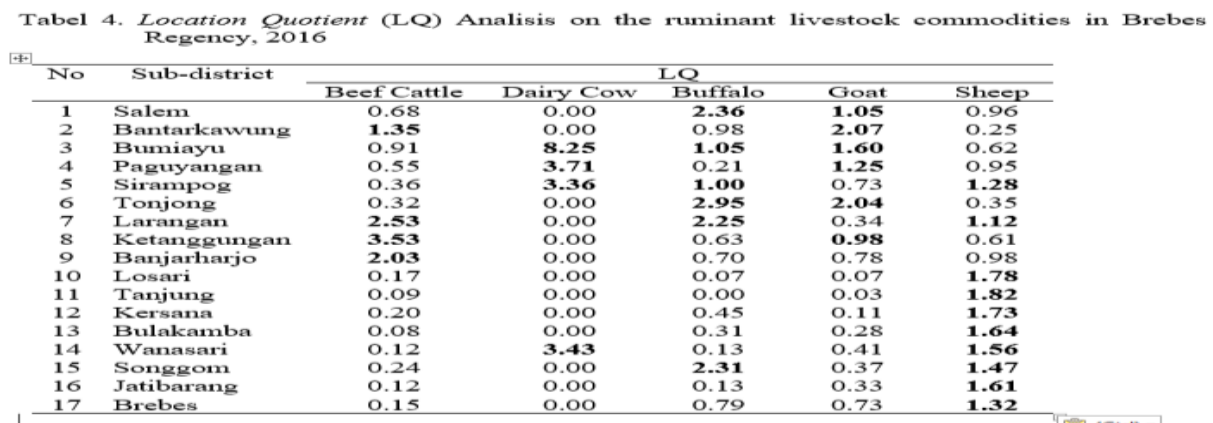

Development II (SWP II) focusing on the agricultural development.

Meanwhile, the other 2 sub-districts (Larangan and Songgom) are located in lowland or population increase by 0.36 percent per year since 2012. This poor population increase becomes a challenge for the Animal Husbandry Office of Brebes Regency northern areas of Brebes Regency. Both subdistricts are included in the Sub-Regional Development III (SWP III) focusing on agricultural and trading sectors. Buffalo in 
those areas is considered a superior commodity when compared to the others. The development of buffalo livestock in those areas relatively has more positive and significant influence when compared to the others. Sugiarto et al. (2017) state that the agro-ecological and livestock regions influence the livestock competitiveness.

Table 5. Regional Shifting Patterns of Buffalo Livestock Central Activities in Brebes Regency, 2012-2016

\begin{tabular}{cllc}
\hline \multirow{2}{*}{ No } & & \multicolumn{2}{c}{ LQ } \\
\cline { 2 - 4 } & & $\mathbf{2 0 1 2}$ & $\mathbf{2 0 1 6}$ \\
\hline 1 & Salem & $\mathbf{2 . 6 5}$ & $\mathbf{2 . 3 6}$ \\
2 & Bantarkawung & 1.00 & 0.98 \\
3 & Bumiayu & $\mathbf{1 . 4 5}$ & $\mathbf{1 . 0 5}$ \\
4 & Paguyangan & 0.28 & 0.21 \\
5 & Sirampog & $\mathbf{1 . 0 1}$ & $\mathbf{1 . 0 0}$ \\
6 & Tonjong & $\mathbf{2 . 5 9}$ & $\mathbf{2 . 9 5}$ \\
7 & Larangan & $\mathbf{2 . 4 0}$ & $\mathbf{2 . 2 5}$ \\
8 & Ketanggungan & 0.40 & 0.63 \\
9 & Banjarharjo & 0.79 & 0.70 \\
10 & Losari & 0.16 & 0.07 \\
11 & Tanjung & 0.00 & 0.00 \\
12 & Kersana & 0.27 & 0.45 \\
13 & Bulakamba & 0.33 & 0.31 \\
14 & Wanasari & 0.17 & 0.13 \\
15 & Songgom & 2.32 & 2.31 \\
16 & Jatibarang & 0.19 & 0.13 \\
17 & Brebes & 0.56 & 0.79 \\
\hline & & & \\
& & &
\end{tabular}

The living creature adaptation ways are highly dependent on the environmental conditions, including physical and chemical conditions as well as the presence of others (Parinding, 2007). The changes of agroclimates, land conditions, and economic demands may encourage the buffalo population changes. However, buffalo is an adaptable living creature to the extremely poor and simple situations. During a period of 2012-2016, the buffalo livestock does not experience regional shifting development. The land area of agricultural crops during the period has not significantly decreased. Based on Table 4, it shows that the central areas of the buffalo activities have not yet changed. In addition, the availability of agricultural land and animal feed as well as the tradition in raising the buffalo also influence the regional shifting patterns of the buffalo development. The tradition in raising the buffalo livestock is not easy to imitate or develop in the other sub-districts. The community environment tends to preserve the buffalo livestock businesses as a job and a way of life custom

\section{Conclusion}

There is no significant change in the agricultural land areas in Brebes Regency, especially those for rice, maize, sweet potato, cassava, and peanut. The rice crop and peanut plant land areas are related to the buffalo population in Brebes Regency.

There is no regional shift pattern of buffalo livestock during a period of 20122016. The buffalo livestock in Brebes regency is centralized in Salem, Bumiayu, Sirampog, Tonjong, Larangan and Songgom sub-district as supported by the conditions with the controlled agricultural land areas and strong tradition in raising the buffalo.

\section{Reference}

BPS Kabupaten Brebes [Central Bureau of Statistics of Brebes Regency]. 2017. Kabupaten Brebes dalam Angka [Brebes Regency in Figures]. Badan Pusat Statistik Kab Brebes [Central Bureau of Statistics of Brebes Regency].

Budiharsono, S. 2001. Teknik Analisis Pembangunan Wilayah Pesisir dan Lautan [An Analytical Technique for the Coastal and Ocean Areas Development]. Pradnya Paramita Jakarta

Ilham, N. 2015. Ketersediaan Produk Samping Tanaman Dan Industri pertanian Sebagai Pakan Ternak Mendukung Peningkatan Produksi Daging Nasional [Side Products Availability of Crops and Agricultural Industry as Feed to Support National Meat Production Enhancement]. Forum Penelitian Agro Ekonomi [Agro-economic Research Forum], Vol. 33 (1) : 47-61

Irshad, A., Tariq, M. M., Bajwa, M. A., Abbas, F., Isani, G. B., Soomro, G. H., Waheed, A.and Khan, K. U. 2011. A study on performance analysis of Holstein-Friesian cattleherd under semi intensive management at Pishin Dairy Farm Balochistan. Journal 
ofInstitute Science and Technology, Igdir, Turkey, 1: 53-57

Johnston, M.P. 2014. Secondary Data Analysis: A Method that which a Time Has Come. Quantitative and Qualitative Methods in Library (QQML) 3.

Mukson, E. Prasetyo, B. M. Setiawan dan H. Setiyawan. 2005. Analisis FaktorFaktor Yang Mempengaruhi Pengembangan Peternakan Di Jawa Tengah [The Analysis of Factors to Influence Agriculture Development in Central Java]. Journal of Animal Agricultural Socio-economics 1 (1):

Parinding. 2007. Potensi dan Karakteristik Bio-Ekologis Tumbuhan Sarang Semut Di Taman Nasional Wasur Merauke Papua [Bio-ecological Ant Nest Plant Potentials and Characteristics in Wasur National Park, Merauke, Papua]. Thesis. Sekolah Pascasarjan IPB [Graduate Program of Agricultural Institute of Bogor]. Bogor.

Sugiarto, M., Y.N.Wakhidati, A. Einstein and Khaerudin. 2017. The Competitiveness of Beef Cattle Business on Various Agro-Ecological Zones in Tegal Regency. Animal Production 19 (2):127-134

Suhartina and I. Susanti. 2017. Strategi Pengembangan Usaha Ternak Kerbau Yang Dipelihara Secara Tradisional Berdasarkan Peluang Dan Tantangan [The Development Strategies of
Buffalo Livestock Traditionally Raised Based on Opportunities and Challenges]. MADURANCH 2 (1): 37-43

Suhubdy, Y., Poerwoto, H., Dania, I.B., Imran, Sofyan, DH., Dilaga, S.H., Muhzi, M., 2005. Profil dan Petensi Kerbau Sumbawa di Propinsi Nusa Tenggara Barat. Suatu Rekaman Pendahuluan Data Dasar Kerbau Lokal [The Profile and Potentials of Sumbawa Buffalo in West Nusa Tenggara Province: An Introductory Basic data Record of the Local Buffaloes]. Fakultas Peternakan Universitas Mataram [Faculty of Animal Sciences, Mataram University]. Mataram.

Sumoprastowo, R.M. 2003. Penggemukan Sapi dan Kebau [Cow and Buffalo Fattening Program]. First Edition. Jakarta: Papas Sinar Sinanti, a Member of Ikapi Jakarta.

Winugroho, M., B. Hariyanto dan K. Ma'sum. 1998. Konsep Pelestarian Pasokan Hijauan Pakan dalam Usaha Optimalisasi Produktivitas Ternak Ruminansia [Forage Supply Preservation Concepts to Optimize the Productivity of Ruminant Livestock]. In: Prosiding Seminar Nasional Peternakan dan Veteriner [National Seminar Proceeding of Animal Husbandry and Veterinary] . Volume I. Puslitbang Peternakan [Research and Development Center of Animal Husbandry]. Bogor 